British Journal of Education

Vol.8, Issue 3, pp.122-133, March 2020

Published by ECRTD- UK

Print ISSN: ISSN 2054-6351

Online ISSN: ISSN 2054-636X

\title{
INDUSTRIAL TRIPS: SIGHT-SEEING OR A LEARNING EXPERIENCE? EXPERIENCES OF STUDENTS IN CAPE COAST TECHNICAL UNIVERSITY
}

\author{
Eugene Owusu-Acheampong \\ Cape Coast Technical University, Department of Secretaryship and Management Studies, P. O. \\ Box DL 50, Cape Coast, Ghana
}

\begin{abstract}
The goal of the study was to examine the effects of industrial trips on student learning outcomes. The specific objectives were to assess student's perception on industrial trips, assess the level of student's involvement in industrial trip activities, determine the hitches militating against the organisation of industrial trips, explore student's experiences about industrial trips and assess the gains students derive from industrial trips. The explanatory sequential mixed method design was used for the study. Stratified and simple random sampling techniques were used to select departments and students for the quantitative part of the study whereas purposive and convenient sampling techniques were employed to select participants for the qualitative part of the study. A sample size of one hundred and eighty-four (184) students from a population of three hundred and forty-two respondents were used for the study. Yamane (1967) formula was used for sample size determination. Questionnaire (closed-ended questions) was the instrument used to collect the quantitative data and semi-structured interviews was used to collect data for the qualitative study. Descriptive and inferential statistics were used to analyse and interpret the quantitative data while thematic analysis (Braun \& Clarke, 2006) was employed to interpret the qualitative data.The study revealed students gain a lot from industrial trip programme as they learn to link theory to practice, establish relationships with experts in industry for career guidance, improve their communication skills, ask job relevant related questions and also establish contact for future industrial attachment placement and subsequent employment in industry. Since the study revealed that industrial trips are useful exercises, it is recommended that it should be continued since it will help enhance the skills and competencies of students, enable them to ask job relevant related questions which will eventually enhance their understanding about theories and concepts taught in class.
\end{abstract}

KEYWORDS: sight-seeing; learning; experience; industrial trips; human resource development

\section{INTRODUCTION}

Contemporary surveys on competencies required by industry revealed a huge gap and generated a number of queries from industry as to skill-gap between theory and practice across many economies. This could be attributable to the system of education that does not allow for link between industry and institutions responsible for human resource development of countries (Azevedo, Apfelthaler \& Hurst, 2012).

The fundamental principle of industrial visits/trips is geared towards the development of the human resource in order to acquire the requisite real world experiences and competencies for better 
British Journal of Education

Vol.8, Issue 3, pp.122-133, March 2020

Published by ECRTD- UK

Print ISSN: ISSN 2054-6351

Online ISSN: ISSN 2054-636X

participation in industry work after school (Kennedy, 2014). It is undoubted that industrial tours or trips are critical to any students or learner receiving professional training in disciplines such as Engineering, Business Management, Procurement, Marketing, Fashion, Tourism, Nutrition, Pharmacy and the like (Greene, Kisida \& Bowen, 2014). Since no institution of higher learning or training has adequate infrastructure to show case all practical and real working machines, equipment, procedures and methods, and all the necessary practical activities that students will come across after completing their respective programmes of study, makes industrial tours or trips a key ingredients in bridging the gap between theory and practice (Azevedo, Apfelthaler \& Hurst, 2012). Technical universities as part of its mandate are to incorporate industrial engagements in its programmes in to adequately prepare students for the world of work. This programme facilitates the development of the human resource in the country for speedy economic growth and development. Successful industrial tours or trips enhance student's ability to establish links and network themselves with professionals in their respective field of study. Industrial trips also provide the students with an opportunity to observe processes at the workplace and gain experiences for career development and to improve interpersonal relation and professional communication skills.

Kisiel, Anderson \& Storksdieck (2006) described industrial trips as the most common learning experiences that take place outside the classroom environment. An example is taking the students on industrial trip is travelling to an industry or institution to observe and learn how work processes take place. Industry trips allow students to view and understand the work environment (Patil, Wagner, Schweisinger, Collins, Gramopadhye \& Hanna, 2012). During industrial trips learners are expected to observe work processes and procedures and write reports on those observations and discuss in class after the trip. Industrial trips, allow learners to see what skills, strategies and technologies that are employed in the workplace (Townsend \& Urbanic, 2013). Industrial trips are expected to offer students the opportunity make contacts and connections with established entrepreneurs and business managers in order to seek clarification and to understand real world situations better (Patil et al., 2012).

Unfortunately, the relevance of industrial trips is gradually being defeated since most students conceive the exercise as an excursion or sight-seeing activity instead of a process of learning. Hence, the expected learning outcomes students are required to gain to enhance their learning and improve upon their competencies become fruitless (Behrendt \& Teresa, 2014; Coughlin, 2010). It is in view of the misconceptions of industrial trips that this study aims to examine the relevance of industrial trips and the challenges associated with it.

The specific objectives were to: assess students' perception about industrial trips, assess the level of student's involvement in industrial trips activities, determine the hitches militating against the organization of industrial trips, explore student's experiences about industrial trips and assess the gains students derive from industrial trips. This study is meant to contribute to the existing body of knowledge in human resource development. The findings are expected to inform policy decision on the best ways to improve industrial trips organisations in institutions. Beside the study is expected to erase the misconceptions of students on industrial trips as a mere excursion or sight- 
British Journal of Education

Vol.8, Issue 3, pp.122-133, March 2020

Published by ECRTD- UK

Print ISSN: ISSN 2054-6351

Online ISSN: ISSN 2054-636X

seeing activity. Additionally, the findings would inform policy decision makers in Technical Universities on the need to improve industrial trip programmes for better learning outcomes for students. Moreover, the findings would also serve as a basis for further research for educators and researchers who would want to research in the area to enhance the development of the human resource.

\section{Students Experiences about Industrial Trips}

Goh (2011) in a study on the value and benefits regarding industrial trips reported that students believe industrial trips are very insightful and educative and therefore happy and willing to partake in any form of trip that will enable them link theory to practice. Participants were hopeful that industrial trips enable them to establish links with key professional in industry which subsequently enables them to secure a place for their attachment. Majority eighty-seven (87\%) of the respondents rated industrial trip as a very good activity. The study also reported that students and course tutors were actively involved in the decision regarding the type of industry to visit and the expected learning outcomes to be derived from such visits. Besides, the study revealed that about 30 percent of students are able to establish network with industry professionals and that have enabled them to secure places for industrial attachment. In a related study by Howard \& Gulawani (2014) revealed that about 20 percent of students who have had previous industrial visits and had completed their course of study secure placement for full employment in industry through the network they had established through industrial trips.

\section{Hitches Militating Against the Organization of Industrial Trips}

Several factors militate against the organisation of industrial trips (Owusu-Acheampong, 2014). In a study conducted by (Howard \& Gulawani, 2014) it was revealed that difficulty in accessing funds for industrial trip on regular basis was a challenges hence, it limited the frequency with which students had opportunities for industrial trips. Behrendt \& Teresa (2014) found that getting access to industry was sometimes a major issue the impeded frequent visits to industries. Kisiel, Anderson \& Storksdieck (2006) also found that limited time for industrial trips due to the overload of courses on lecturers was also an issue of concern. Greene, Kisida \& Bowen (2014) study revealed long distance from school to industry made some students and teachers feel reluctant to embark on industrial trips because of the fatigue in sitting in buses for long hours. The study further indicated lack of student's involvements on decision about the place of visit as a factor that militates against industrial visit.

\section{The Gains Students Derive from Industrial Trips}

According to Higgins, Dewhurst \& Watkins (2012) students are motivated and encouraged to partake in industrial trips. Their interest is gingered by the perceived benefits that they are likely to gain during industrial trips. Such benefits include: the opportunity to learn from the professionals in the industry, relate abstract concepts in the class to the real world of work, opportunity to identify prospective areas of work in the future, opportunities to observe and see best practices used by different organization, opportunity to identify modern technologies employed in the process of work, establish links and network with professionals and managers for future industrial attachment placement and employment opportunities, improved communication 
British Journal of Education

Vol.8, Issue 3, pp.122-133, March 2020

Published by ECRTD- UK

Print ISSN: ISSN 2054-6351

Online ISSN: ISSN 2054-636X

skills and the opportunity to ask job relevant related questions. Students also become aware of industry practices and regulations during industry visits. Industrial visit broadens student's outlook and exposes them to different workforces from different industries (McCarthy, 2010).

\section{METHODOLOGY}

The explanatory sequential mixed method approach was used for the study. For the quantitative aspect of the study, a sample size of 184 students participated in the study. A total of 170 questionnaire were retrieved representing 92 per cent. Stratified and simple random sampling techniques were used to select departments and participants respectively for the quantitative study. Data collection method for the quantitative aspect was questionnaire administration and the instrument was questionnaire. Yamane (1967) sample size formula was used to calculate a sample size of 184 from a population of 342. The quantitative data obtained was analysed using IBMSPSS software. The results was analysed using descriptive and inferential statistics. The qualitative bit of the study involved four (4) key informants and six (6) students who were purposively and conveniently sampled respectively. The data collection method for the qualitative part was interviewing. Semi-structured interviews and Focus Group Discussion Guide were used to collect the qualitative data. Data obtained was analysed thematically using Braun \& Clarke (2006) thematic procedure. Both qualitative and quantitative findings were triangulated and synthesized.

\section{RESULTS AND DISCUSSIONS}

\section{Students Perception of Industrial Trip}

Table 1: Perception of Students on Industrial Trip

\begin{tabular}{lcl}
\hline Responses & Frequency & Percentage \\
\hline Excellent & 20 & 11.7 \\
Very Good & 49 & 28.8 \\
Good & 70 & 41.1 \\
Satisfactory & 29 & 17.0 \\
Poor & 2 & 1.17 \\
\hline Total & $\mathbf{1 7 0}$ & $\mathbf{1 0 0}$ \\
\hline
\end{tabular}

Source: Field survey, 2019

Table 1 represents perceptions of students about the industrial trip programme. Students were made to express their views as to whether industrial trip activities are excellent, very good, good, satisfactory and poor. Responses obtained showed that most of the students' constituting 44 percent perceived industrial trip as a good activity. Other category of participants who represent 28.8 percent classified the activity as very good followed by 17.0 percent who opined that the activity is satisfactory, then 11.7 percent expressed that the activity is excellent and 1.7 percent 
British Journal of Education

Vol.8, Issue 3, pp.122-133, March 2020

Published by ECRTD- UK

Print ISSN: ISSN 2054-6351

Online ISSN: ISSN 2054-636X

regarded it as poor. Most participants expressed the view that industrial trip is a good activity programme.

As to the perceived benefits of industrial trip, 161 (94.7\%) of participants agreed that the industrial trip experience is very useful. Factors cited for the usefulness of the activity as experienced were ranked and they included; ability to relate concepts and theory to practice $(95.3 \%)$, ability to interact with professionals within the industry (93.1\%), ability to identify prospective areas of work in the future $(78.9 \%$ ), and ability to establish connections and networks for future industrial attachment placement, and for national service and future employment in the industry.

\section{Hitches Militating Against the Organization of Industrial Trips}

Interview responses from Respondent 1 (Key Informant) on how industrial trips are organized reads as follows:

'You know we don't lecture the students. We believe when they go out for industrial trip, they are going there to learn some practical things from the theory taught from lecture room. So we don't force or push students in any place at all. What we do is you know we have liaison coordinators for each department so we ask the coordinators to liaise with the lectures so we know where they would want to take the students to visit for a particular year. We normally call for three (3) places with the hope that at least we will get one of them. When we are given that placement from the departmental coordinators who have liaised with the lecturers and heads of departments, then we move out to the organisations with letters to look for the places for the trip. Actually, not all the organisations do accept us readily. At times we have to make about 3 or 4 follow-ups before the students are admitted or allowed to visit the organization or institution. Scouting for the industry for industrial trips has not been an easy job'. The finding relating to scouting for industry for industrial trip correspond to Behrendt \& Teresa (2014) study that found getting access to industry was sometimes a major issue that impeded frequent visit to industry for trips.

In a related interview with key informant 2 , it was revealed:

"The industrial trip start from the department. We only facilitate it. If you have taught the students, you have to tell us that you want an organization where they can learn what you have taught them practically. We come in to help when looking at the distance involved. Sometimes, when we have a similar organization in or around the metropolis, we would not advise that the students travel very far when they can learn those things within organisations nearby. We come in as advisory sort of unit but the choice of the industry come from the department. We only advise when the need arises. The departments tell us where they want to go and we look for placement eg. If you tell us you want to go to Melcom, we go and look for placement or we search for the placement for them".

Generally, responses from the key informants disclosed that challenges confronting the arrangements of industrial trip include: management support, industry specifications, coordinators/lecturers related challenges and students unwillingness and participation.

Management support: the interviews revealed delay in release of funds, difficulty in fueling buses or vehicles for industrial trips, difficulty in getting a driver for industrial trips, and difficulty in getting approval for industrial trip. This report is consistent and confirms the findings of Higgins, 
British Journal of Education

Vol.8, Issue 3, pp.122-133, March 2020

Published by ECRTD- UK

Print ISSN: ISSN 2054-6351

Online ISSN: ISSN 2054-636X

Dewhurst \& Watkins (2012), whose study revealed that difficulty in accessing funds for field trips on regular basis as a major challenge hence; it limited the frequency with which students had to embark on industrial trips. Besides, the study revealed an absence of policy document on industrial trip.

Industry related challenges: these include industry specification on a particular number of students an industry expects to visit as against the total number of students in a class expected to embark on industrial trip at a given time.

Students related challenges: there is a problem of student's apathy and unwillingness to participate in industrial trip. Some students don't take the exercise seriously, students insisting on visiting a place of interest to them and not the one recommended by the liaison unit/coordinators, drivers reporting on students misconduct (noise making in the bus, delay in boarding the vehicle at the prescribed time to and from industry and loitering in the bus.), long hours for lunch disrespecting time and students refusal to visit places within Cape Coast or within the Central Region. From one key respondents, it was reported that;

"Apathy-that when they are not travelling outside Cape Coast. It has become like sight-seeing. It has become like we have paid for industrial trip so we must travel. They feel like if you go to industry within Cape Coast, they have not travelled and also have not used their money enough so it is student apathy on industrial trip that is our major challenge. When we are travelling within Cape Coast, only few students will participate in the trip but if we travel outside Cape Coast almost all about 80 percent of the students will participate".

Coordinators/lecturers related challenges: most of the time, only national service personnel or teaching assistants accompany students to industrial trips without the department liaison coordinator or the subject lecturers. On lecturer's related issues, one respondent had this to say

"They are not ready to travel. So when we don't get a lecturer on board, the trip has to be cancelled. Cancelling a trip is not a choice. Some lecturers unwilling to cancel their lectures to allow for industrial trip. We are not getting support from the department eg. A lecturer fixing date for quizzes on a day of trip. I can't tell if the industrial liaison coordinators are not informing lecturers".

One key informant had this to say about industrial trip: 'the responsibility of industrial trips is with the department industrial coordinator. There are few occasions that I am informed about industrial trip activities. Sometimes before I am aware, then the students had already gone for the trip. Ideally, I think it is an important activity that all staff and heads of departments must get involved. Most of us see it to be the work of the industrial liaison office and perhaps the industrial liaison coordinators of the departments.

Challenges Facing the Industrial Liaison Unit An interaction with one of the key informants disclosed: "We lack the logistics eg. No internet connectivity in the office to liaise or communicate with industries, no telephone line in the office to communicate with industry, I even don't have a 
British Journal of Education

Vol.8, Issue 3, pp.122-133, March 2020

Published by ECRTD- UK

Print ISSN: ISSN 2054-6351

Online ISSN: ISSN 2054-636X

printer in my office. The liaison office is woefully under resource, no vehicle for the liaison unit. Our challenges are many".

\section{Student's Experiences about Industrial Trip}

A student respondents had this to say 'I like industrial trips. I get to know places I don't know. To me I learn and observe things whether it is taught in class or not'.

Another student respondents had this to say: 'industrial trips are good. I like it. It helps me know what the companies do. I am able to see things for myself. I look at how people dress to work, the machines they work with and how those machines function. I am able to ask questions and this helps me to take my industrial attachment seriously'.

An interview with another student respondent revealed: 'to me the trip is wonderful but many at times we I mean we the students are not told where we are visiting early. Sometimes, we hear colleagues say we will go to Accra for industrial trip a day before the trip but they themselves may not even know the company we shall be visiting. This is very bad' I think we need to know where we are going for the visit early so that we can prepare and get ready to ask questions and learn not only to see things for ourselves'.

Gains Students Derive from Industrial Trips

Table 2: Correlation of industrial trips programme on students

\begin{tabular}{lllll}
\hline & & $\begin{array}{l}\text { Ability to } \\
\text { Learn }\end{array}$ & $\begin{array}{l}\text { Improve } \\
\text { com. skills }\end{array}$ & $\begin{array}{l}\text { Ask career } \\
\text { related questions }\end{array}$ \\
\hline Industrial & Pearson & .372 & .353 & .269 \\
Trip & Sig & .000 & .000 & .000 \\
& $\mathrm{~N}$ & 170 & 170 & 170 \\
\hline
\end{tabular}

Source: Field survey, 2019 Correlation is Significant at .0.05

Table 2 depicts the relationship between industrial trips and students learning outcomes. The study revealed variables such as ability to learn during industrial trips, improve communication skills and ask career related questions. These variables were measured at 5\% significant level. The results showed that there is statistical significant relationship between the all variables and industrial trip with p-value of 0.000 which is less than alpha 0.05 . The implication is that as students embark on industrial trip, they are able to learn, improve their communication skills, and enable them to ask career related questions in order to be better informed in their career choice. The correlation coefficient for ability to learn was .372 , .353 for improves communication skills and .269 for ability to ask career related questions. Though the correlation coefficients showed a positive relationship, the strength of the relationship was weak. 
British Journal of Education

Vol.8, Issue 3, pp.122-133, March 2020

Published by ECRTD- UK

Print ISSN: ISSN 2054-6351

Online ISSN: ISSN 2054-636X

Table 3: Means of Benefits Students Derive from Industrial Trip

\begin{tabular}{lllllr}
\hline Variables & N & Min & Max & Mean & Std Dev. \\
\hline Learn and link theory to practice & 170 & 1 & 5.00 & 4.0235 & .98481 \\
IT improve communication skills & 170 & 1 & 5.00 & 3.6706 & 1.01338 \\
Give confident to ask job related questions & 170 & 1 & 5.00 & 4.0353 & .97843 \\
& & & & & \\
\hline
\end{tabular}

Scale: 1 Strongly Disagree, 2 Disagree, 3 Uncertain, 4 Agree, Strongly Agree

Source: Field survey, 2019

Table 3 looked at the means of the gains students derive from embarking on industrial trips using ability to learn and link theory to practice, improve communication skills and gives confident to ask job related questions using a scale of 1-5. The study found the mean of industrial trip able to give students confident to ask job related questions to be 4.0353 as most benefits students derive from industrial trip followed by ability to learn and link theory to practice as the second gain and the ability to improve their communication skills as the least benefits derived from embarking on industrial trip. It can therefore be concluded that as students embark on industrial trip activity, they are able to gain confidence to ask job related questions in their field of study.

\section{Level of Student's Involvement in Industrial Trip Activities}

In a Focus Group Discussion held with ten students, it was revealed that student's inability to partake in industrial trip was due to lack of involvement in decisions as to the place to visit for the trip. They indicated that sometimes they do not know the specific skill to learn and observe when they go for industrial trip. The study revealed that students sometimes go for industrial trips with the department liaison coordinator and other times a national service person or a teaching assistant who perhaps may not be a course lecturer. They further indicated that since in most occasions they do not know what specific skill to learn in that industry, they consider the visit to be a sight-seeing activity.

A student respondent in an interview had this to say: "I was there a day when the course representative put on our WhatsApp platform, we shall be going on an industrial trip a day after. I was seriously preparing for a quiz. The notice was very short. I did know what I was going to learn there. I only join the bus the next day and when I got to see the place, my friend and I visited another friend in a sister institution. While we were there, a friend call that the bus is ready to move back to campus so, we rushed to the industry and sat in the bus back to campus".

Another student respondent had this to say: 'We are not involved in the decision about industrial trips. We are only informed some few days to the trip about the place of visit. We usually don't know the things to learn. We get to the industry, and an attendant or representative takes us round to all sections. Some colleagues usually ask questions on the activities we had observed but in most cases most of the questions are based on what we had observed but not linked to any specific theory we have learnt in the lecture hall'. 
Table 4: Means of Levels of Involvement in Deciding On Industrial Trip

\begin{tabular}{llllll}
\hline Variables & N & Min & Max & Mean & Std Dev. \\
\hline Industry to Visit & 170 & 1.00 & 5.00 & 2.4588 & 1.44773 \\
Skills to Be Learnt & 170 & 1.00. & 5.00 & 2.4941 & 1.48860 \\
Time to Be Spent & 170 & 1.00 & 5.00 & 2.3529 & 1.52847 \\
\hline
\end{tabular}

Scale: 1 Strongly Disagree, 2 Disagree, 3 Uncertain, 4 Agree, Strongly Agree Source: Field survey, 2019

Table 4 depicts student's level of involvement on in industrial trip activity with particular reference to the selection of industry to visit, the skills expected to be learnt during industrial visits and the time to be spent during the visit. The results generally showed a low level of involvement in all the three variables. Though students partaking in decision as to the skills to learn while on industrial trip happened to be the first among the variables, with a mean of 2.4941. This was low compared with the scale of measurement, followed by involvement in deciding on the type of industry to visit (2.4588) and the time to spend in industry during industrial visit (2.3529). These outcomes contradict Mitchell, Turner, Montgomery \& Hartley (2017) report which stated students are actively involved in decision making as to where to have industrial trip.

Correlation analysis showed a positive relationship between industrial trip and student's ability to learn. Though it was seen to have very low relationship however, the p-value produces a statistical significant result 0.042 which is less than alpha (0.05). This showed there is a statistical significant relationship between industrial trip programme and students ability to learn during industrial trip. The implication is that as students embark on industrial trip, they learn.

\section{Summary}

The study revealed majority of students had a positive perception on industrial trip activity. They believed industrial trip is a good programme and should be embarked continued.

The findings also showed students are not actively involved in deciding on the type of industry to visit, the particular skills to learn during industrial trip and the hours to be spent during industrial trip.

The study also revealed students gain a lot from industrial trip programme as they learn to link theory to practice, establish relationships with experts in industry for career guidance, improve their communication skills, ask job relevant related questions and also establish contact for future industrial attachment placement and subsequent job placement.

Despite the positive perception about industrial trip a fraction of the studied sample (though in the minority), regarded the exercise as a sight-seeing programme.

The study also revealed difficulties in getting a particular industry for visit, some students unwillingness to participate in the programme, some lectures unwillingness to participate in the 
programme, and woefully inadequate logistics and resources such as internet connectivity, telephone, printer and vehicles as some of the challenges confronting the liaison unit in their quest to render effective services.

\section{CONCLUSIONS}

Industrial trips are very useful and provide students with the ability to learn and relate theory to practice; it is not just a mere sight-seeing activity but rather a learning process that equips students with competencies for their own development. Notwithstanding the gains derived from the activity, the students are not active participants in deciding on the type of industry to visit. Besides, getting an industry to visit and learn sometimes proves to be very difficult. Also the liaison unit is not adequately resourced for its duties and responsibilities.

\section{Recommendations}

i. Since the study revealed that industrial trips are useful exercise, it is recommended that it should be continued since it will help enhance the skills and competencies of students, enable them to ask job relevant related questions which will eventually enhance their understanding about theories and concepts taught in class.

ii. Since the study revealed that some students (though in the minority) consider industrial trips as an excursion or a sight-seeing activity, it is recommended that heads of various academic departments, industrial coordinators, lecturers and the liaison unit organise workshops at least once every year to sensitise students on the relevance of the industrial trip programme as it will enable the students acquire competencies for future employment.

iii. Since the study revealed that the decision as to what industry to visit has limited or low students participation, it is recommended that all stakeholders (students, subject lecturers, industrial coordinators and liaison unit) must collectively make such decisions as to what industry to visit and decide on the learning outcomes expected. This will make the students take interest and learn during industrial trips.

iv. As regards the challenges associated with the conduct of industrial trips, it is recommended that management must endeavour to speedily approve, release funds and vehicles for industrial trips. The management of the university must resource the industrial liaison unit with the necessary logistics and equipment to be more effective and responsive to the needs of the students. In addition, course lecturers must brief students on the expected outcomes of each trip before embarking on it. Furthermore, the university must institute measures to discipline students who misconducts themselves during industrial trips. This will serve as a deterrent for others.

v. Since the study revealed the institution has not got industrial trip policy, it is recommended that the liaison unit, industrial liaison coordinators, heads of departments and the Students 
British Journal of Education

Vol.8, Issue 3, pp.122-133, March 2020

Published by ECRTD- UK

Print ISSN: ISSN 2054-6351

Online ISSN: ISSN 2054-636X

Representative Council cooperate and work together to produce a policy document that will guide industrial trip programmes in the institution since it will help streamline industrial trips programmes within the institution.

\section{Suggestions for Further Studies}

This study aimed at understanding the perceptions and gains derived from industrial trips. It is believed that there are other areas that could be research e.g. evaluating the effectiveness of the industrial trip programme.

\section{Reference}

Azevedo, A., Apfelthaler, G., \& Hurst, D. (2012). Competency development in business graduates: An industry-driven approach for examining the alignment of undergraduate business education with industry requirements. The International Journal of Management Education, 10(1), 12-28.

Behrendt, M \& Teresa, F (2014). "A review of research on school field trips and their value in education," International Journal of Environmental \& Science Education, Vol. 9 No. 3, pp. 235-245.

Braun, V., \& Clarke, V. (2006). Using thematic analysis in psychology. Qualitative research in psychology, 3(2), 77-101.

Coughlin, P (2010). "Making field trips count: collaborating for meaningful experiences," The Social Studies, Vol. 101 No. 5, pp. 200-210.

Goh, E (2011). "The value and benefits of field trips in tourism and hospitality education," Higher Learning Research Communications, Vol. 1 No. 1, pp. 60-70.

Greene, J. P., Kisida, B., \& Bowen, D. H. (2014). The educational value of field trips: Taking students to an art museum improves critical thinking skills, and more. Education Next, 14(1), 78-87.

Higgins, N., Dewhurst, E., and Watkins, L., (2012). "Field Trips as Short-Term Experiential Learning Activities in Legal Education”, the Law Teacher, Vol. 46, No. 2, 165-178

Howard, K., \& Gulawani, M. (2014). Student perceptions of study tour learning: A case study. Aweshkar Research Journal, 18(2), 101-114

Kennedy, M. D., (2014) “The Benefit of Field Trips”, University Honors Program Theses. Paper 60 (2014).

Kiplagat, H, Khamasi, J. W \& Kare, R (2016). Students' Experience of Industrial Attachment: A Case of a Public University. Journal of African Studies in Educational Management and Leadership Vol: 7No:1, August 2016, 82-97

Kisiel, J., Anderson, D., and Storksdieck, M. (2006). Understanding teachers' perspectives on field trips: Discovering common ground in three countries. Curator: The Museum Journal, 49: 365-386.

McCarthy, M. (2010). Experiential learning theory: From theory to practice. Journal of Business \& Economics Research, 8(5), 131-139. 
Vol.8, Issue 3, pp.122-133, March 2020

Published by ECRTD- UK

Print ISSN: ISSN 2054-6351

Online ISSN: ISSN 2054-636X

Mitchell, M., Turner, G., Montgomery, R., \& Hartley, M. (2017). Field Trip! Assessing Business Student Interest in Plant Tours and Their Product Categories. Atlantic Marketing Journal, 5(3), 7.

Owusu-Acheampong, E. Asamoah, A. W. \& Azu T. D. (2014). Industrial Attachment: Perspectives, Conceptions and Misconceptions of Students at Cape Coast Polytechnic. Journal of Education and Practice Vol.5, No 37

Patil, R., Wagner, J., Schweisinger, T., Collins, R., Gramopadhye, A., \& Hanna, M. (2012). A multi- disciplinary mechatronics course with assessment-Integrating theory and application through laboratory activities. International Journal of Engineering Education, 28(5), 1141-1149.

Townsend V\& Urbanic J (2013), "Industrial field trips: An integrated pedagogical framework of theory and practice”, International Journal of Engineering Education, Vol. 29, No. 5, pp. $1155-1165$. 